\title{
ASSESSMENT OF GROUNDWATER QUALITY FOR DRINKING PURPOSE IN BARWALA TOWN AND ITS SURROUNDINGS, PANCHKULA DISTRICT, HARYANA, INDIA
}

\author{
Anup Kumar ${ }^{1 *}$, Yukta ${ }^{2}$ and V.S. Arya ${ }^{3}$ \\ ${ }^{1}$ Front Office-HARSAC, Panchkula, India \\ ${ }^{2}$ Govt. ITI, Panchkula, India \\ ${ }^{3}$ Haryana Space Applications Centre (HARSAC), Hisar, India
}

Received on: 03.08.2020

\begin{abstract}
Water is important for drinking, agriculture and industrial purposes. Water quality plays vital role in its utilization for different purposes. Water quality for drinking purpose should be as per BIS drinking water standards (IS 10500:2012). Barwala town in Panchkula district, Haryana, India has been selected in the present study for groundwater quality assessment for drinking purpose. In the study area six groundwater samples were collected in the month of June 2019 in plastic $250 \mathrm{ml}$ bottles. Geocoordinates of the sample locations were noted with mobile GPS. Groundwater samples were analysed using Field Water Testing Kit prepared by Tamil Nadu Water Supply and Drainage Board (TWAD) Chennai for ten chemical parameters-pH, hardness, chloride, fluoride, iron, ammonia, nitrite, nitrate, phosphate and residual chlorine. In the study area $\mathrm{pH}$ ranges from 7 to 8, hardness ranges from $150 \mathrm{mg} / \mathrm{l}$ to 400 $\mathrm{mg} / \mathrm{l}$, chloride ranges from $100 \mathrm{mg} / \mathrm{l}$ to $150 \mathrm{mg} / \mathrm{l}$, fluoride ranges from $0.5 \mathrm{mg} / \mathrm{l}$ to 2 $\mathrm{mg} / \mathrm{l}$, iron ranges from $0 \mathrm{mg} / \mathrm{l}$ to $5.0 \mathrm{mg} / \mathrm{l}$, ammonia ranges from $0.5 \mathrm{mg} / \mathrm{l}$ to $5.0 \mathrm{mg} / \mathrm{l}$, nitrite ranges from $0.2 \mathrm{mg} / \mathrm{l}$ to $1 \mathrm{mg} / \mathrm{l}$, nitrate ranges from $45 \mathrm{mg} / \mathrm{l}$ to $150 \mathrm{mg} / \mathrm{l}$, phosphate ranges from $0.5 \mathrm{mg} / \mathrm{l}$ to $1.0 \mathrm{mg} / \mathrm{l}$ and residual chlorine ranges from $0 \mathrm{mg} / \mathrm{l}$ to $0.5 \mathrm{mg} / \mathrm{l}$. In the study area groundwater quality is non-potable in five groundwater samples and potable in one groundwater sample. The study is highly useful for monitoring of groundwater quality for drinking purpose in the study area.
\end{abstract}

Accepted on: 01.10. 2020

\author{
Keywords \\ Groundwater, quality, drinking, \\ Barwala, Panchkula, Haryana.
}

\section{Introduction}

Water is important for drinking, agriculture and industrial purposes. Availability of good quality groundwater plays vital role in developmental activities. But the present developmental activities adversely affected the surface and groundwater quality as well as quantity. In urban areas sewerage and solid waste are mainly responsible for polluting the groundwater quality. Many workers have done work on groundwater quality assessment for drinking purpose in urban and rural areas. Some important studies are reported by Agrawal (2009), Ana et al. (2018), Balakrishnan, et al (2011), Das and Nag (2015),Durgadevagi, et al. (2016), Hussain and Prasad (2013). Jeihouni, et al. (2014), Mahadevaswamy, et al. (2011), Okoye, et al. (2016), Pandian and Jeyachandran (2014), Patel and Dhiman (2011), Rajesh, (2016),Sarkar, et al. (2012),Satyanarayana, et al. (2013),Saxena and Saxena
(2015), Sengupta and Dalwani (2008), Shahida and Ummatul (2015), Sheikh and Kumari (2017), Sinha, et al. (2018), Subramani, et al. (2012), Thomas et al. (2015), Topper and Horn (2011), Vashisth (2017).

\section{Study Area}

The study area Barwala Town and its surroundings covers $7921850.61 \mathrm{~m}^{2}$ area and lies between the latitude $30^{\circ} 34$ '33.72" N- 30 32'25.01" N and longitude 76 ${ }^{\circ} 55^{\circ} 37.74 " E-76^{\circ} 57^{\prime} 22.05^{\prime \prime}$ E (Figure1).Barwalais a sub-tehsil in the Panchkula District of Haryana State. Barwala is located $20 \mathrm{~km}$ towards south from Panchkula the district headquarters. The total geographical area of the town is 439 hectares and population 8,307 and about 1,569 houses. Barwala as a block consists of 35gram panchayats and 10 block sameeties. 


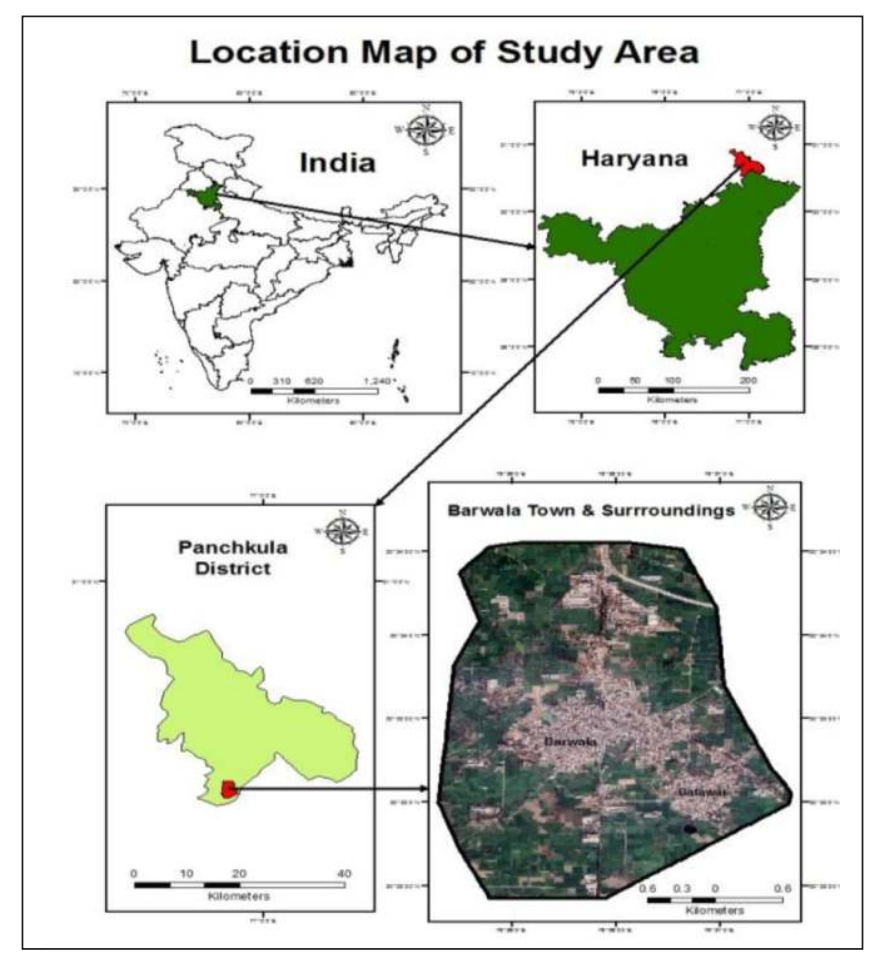

Figure 1: Location map of the study area.

\section{Objective}

The main objective of the study was to assess groundwater quality for drinking purpose in the study area.

\section{Materials and Methods}

Six groundwater samples were collected during field visit in the month of June 2019 in plastic $250 \mathrm{ml}$ bottles (Table 1). Geo-coordinates of groundwater sample locations were noted using mobile GPS. Chemical analysis of groundwater samples was done using Tamil Nadu Water Supply and Drainage Board (TWAD), Chennai - prepared Field Water Testing Kit for ten chemical parameters- $\mathrm{pH}$, hardness, chloride, fluoride, iron, ammonia, nitrite, nitrate, phosphate and residual chlorine(Table2). The groundwater samples analysis results have been categorized as desirable, permissible and non-potable on the basis of BIS Drinking Water Standards (IS 10500:2012) (Table3).

\section{Results and Discussion}

\section{pH}

In the study area $\mathrm{pH}$ varies from 7 to $8 . \mathrm{pH}$ is desirable in all the six groundwatersamples-Shiv Colony-S1, Barwala (8.0), Near Bhareli Road, Barwala (7.0), Shiv Colony-S2, Barwala (7.5), Power House Colony-S1, Batawar, Near Bhagwanpur Road, Batawar (7.5) and Power House Colony-S2, Batawar (7.0) (Figure 2).



Figure 2: pH in groundwater samples.

Table 1: Groundwater sample locations in the study area.

\begin{tabular}{|l|l|l|l|l|}
\hline S. No. & $\begin{array}{l}\text { Sample } \\
\text { Location }\end{array}$ & Source & Latitude & Longitude \\
\hline 1. & $\begin{array}{l}\text { Shiv Colony-S1, } \\
\text { Barwala }\end{array}$ & Hand Pump & $30.556763^{\circ}$ & $76.943313^{\circ}$ \\
\hline 2. & $\begin{array}{l}\text { Near Bhareli } \\
\text { Road, Barwala }\end{array}$ & Hand Pump & $30.554332^{\circ}$ & $76.938308^{\circ}$ \\
\hline 3. & $\begin{array}{l}\text { Shiv Colony-S2, } \\
\text { Barwala }\end{array}$ & Tube Well & $30.557629^{\circ}$ & $76.942901^{\circ}$ \\
\hline 4. & $\begin{array}{l}\text { Power House } \\
\text { Colony-S1, } \\
\text { Batawar }\end{array}$ & Tube Well & $30.557288^{\circ}$ & $76.947365^{\circ}$ \\
\hline 5. & $\begin{array}{l}\text { Near } \\
\text { Bhagwanpur } \\
\text { Road, Batawar }\end{array}$ & Tube Well & $30.552843^{\circ}$ & $76.946186^{\circ}$ \\
\hline 6. & $\begin{array}{l}\text { Power House } \\
\text { Colony-S2, } \\
\text { Batawar }\end{array}$ & Hand Pump & $30.557135^{\circ}$ & $76.947375^{\circ}$ \\
\hline
\end{tabular}

Table 2: Results of chemical analysis of groundwater samples.

\begin{tabular}{|c|c|c|c|c|c|c|c|c|c|c|c|}
\hline $\begin{array}{l}\text { S. } \\
\text { No. }\end{array}$ & Sample Location & pH & $\begin{array}{c}\text { Hardness } \\
(\mathrm{mg} / \mathrm{l})\end{array}$ & $\begin{array}{c}\text { Chloride } \\
(\mathrm{mg} / \mathrm{l})\end{array}$ & $\begin{array}{l}\text { Fluoride } \\
(\mathrm{mg} / \mathrm{l})\end{array}$ & $\begin{array}{l}\text { Iron } \\
(\mathrm{mg} / \mathrm{l})\end{array}$ & $\underset{(\mathrm{mg} /)}{\text { Ammonia }}$ & $\begin{array}{l}\text { Nitrite } \\
(\mathrm{mg} / \mathrm{l})\end{array}$ & $\begin{array}{l}\text { Nitrate } \\
(\mathrm{mg} /)\end{array}$ & $\begin{array}{c}\text { Phosphate } \\
(\mathrm{mg} / \mathrm{l})\end{array}$ & $\begin{array}{c}\text { Residual } \\
\text { Chlorine } \\
(\mathrm{mg} / \mathrm{l})\end{array}$ \\
\hline 1. & Shiv Colony-S1, Barwala & 8.0 & 250 & 150 & 0.5 & 1.0 & 2.0 & 0.5 & 100 & 1.0 & 0.2 \\
\hline 2. & Near Bhareli Road, Barwala & 7.0 & 400 & 100 & 1.0 & 2.0 & 5.0 & 0.2 & 150 & 0.5 & 0.5 \\
\hline 3. & Shiv Colony-S2, Barwala & 7.5 & 400 & 150 & 1.0 & 5.0 & 0.5 & 0.2 & 45 & 0.5 & 0.2 \\
\hline 4. & Power House Colony-S1, Batawar & 7.5 & 150 & 150 & 1.0 & 0.3 & 5.0 & 1.0 & 100 & 0.5 & 0.2 \\
\hline 5. & Near Bhagwanpur Road, Batawar & 7.5 & 310 & 150 & 1.0 & 0 & 0.5 & 0.2 & 45 & 1.0 & 0 \\
\hline 6. & Power House Colony-S2, Batawar & 7.0 & 300 & 100 & 0.5 & 0.3 & 5.0 & 0.5 & 100 & 1.0 & 0.2 \\
\hline
\end{tabular}


Table 3: BIS drinking water standards (IS 10500:2012)

\begin{tabular}{|c|c|c|c|c|}
\hline \multirow{2}{*}{$\begin{array}{l}\text { S. } \\
\text { No. }\end{array}$} & \multirow[t]{2}{*}{ Constituent } & \multicolumn{2}{|c|}{ Potable } & \multirow[t]{2}{*}{ Non-Potable } \\
\hline & & Desirable & Permissible & \\
\hline 1. & $\mathrm{pH}$ & 6.5 to 8.5 & - & $<6.5$ to $>8.5$ \\
\hline 2. & Total Hardness (mg/l) & $<200$ & $200-600$ & $>600$ \\
\hline 3. & Chloride (mg/l) & $<250$ & $250-1000$ & $>1000$ \\
\hline 4. & Fluoride (mg/l) & $<1.0$ & $1.0-1.5$ & $>1.5$ \\
\hline 5. & Iron (mg/l) & $<0.3$ & - & $>0.3$ \\
\hline 6. & Ammonia (mg/l) & $<0.5$ & - & $>0.5$ \\
\hline 7. & Nitrite (mg/l) & $<1.0$ & - & $>1.0$ \\
\hline 8. & Nitrate (mg/l) & $<45$ & - & $>45$ \\
\hline 9. & Phosphate (mg/l) & $<1.0$ & - & $>1.0$ \\
\hline 10. & Residual Chlorine (mg/l) & $<0.2$ & $0.2-1$ & $>1.0$ \\
\hline
\end{tabular}

\section{Hardness}

In the study area, hardness ranges from $150 \mathrm{mg} / \mathrm{l}$ to $400 \mathrm{mg} / \mathrm{l}$. Hardness is desirable in groundwater sample at Power House Colony-S1, Batawar (150 mg/L) and permissible in groundwater samples at Shiv Colony-S1, Barwala (250 mg/l), Near Bharel Road, Barwala (400 mg/l), Shiv Colony-S2, Barwala (400 mg/l), Near Primary Health Centre, Barwala (360 mg/l),NearBhagwanpur Road, Batawar (310 mg/l), Power House Colony-S2, Batawar (300 mg/l) (Figure 3).

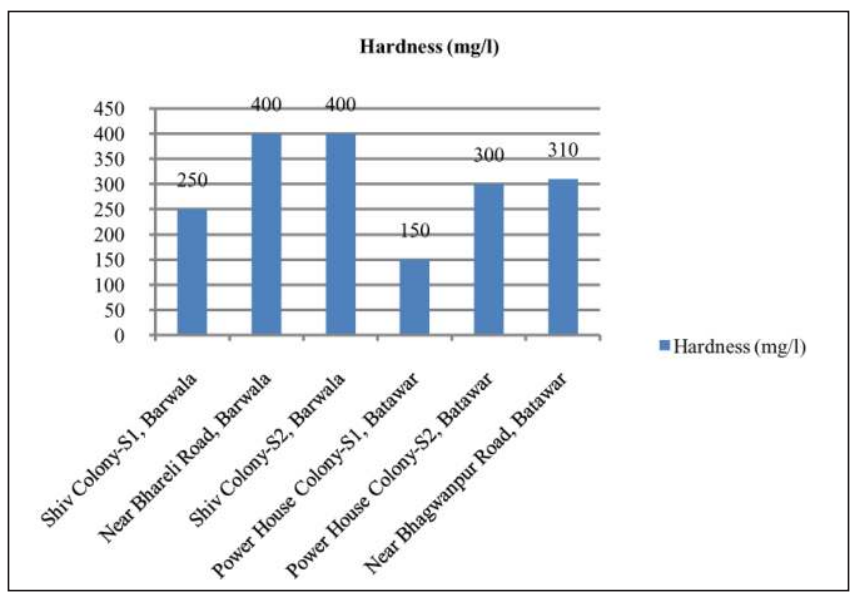

Figure 3: Hardness in groundwater samples.

\section{Chloride}

In the study area, chloride ranges from $100 \mathrm{mg} / \mathrm{l}$ to $250 \mathrm{mg} / \mathrm{l}$. Chloride is desirable in all the sixgroundwater samples - Shiv Colony-S1, Barwala (150 mg/l), Near Bhareli Road, Barwala (100 mg/l), Shiv Colony-2, Barwala (150 mg/l), NearBhagwanpur Road, Batawar (150 mg/l), Power House Colony-S2, Batawar (100 mg/l), Power House Colony-S1, Batawar (150 mg/) (Figure 4).

\section{Fluoride}

In the studyarea, fluoride ranges from $0.5 \mathrm{mg} / \mathrm{l}$ to 1 $\mathrm{mg} / \mathrm{l}$.Fluoride is desirable in all the six groundwater samples at Shiv Colony-S1, Barwala (0.5 mg/l), Near Bhareli Road,
Barwala (1.0 mg/l), ShivColony-S2, Barwala (1.0 mg/l), Power House Colony-S1, Batawar (1.0 mg/l), Near Bhagwanpur Road, Batawar (1.0 mg/l), Power House Colony-S2, Batawar (0.5 mg/l) (Figure 5).

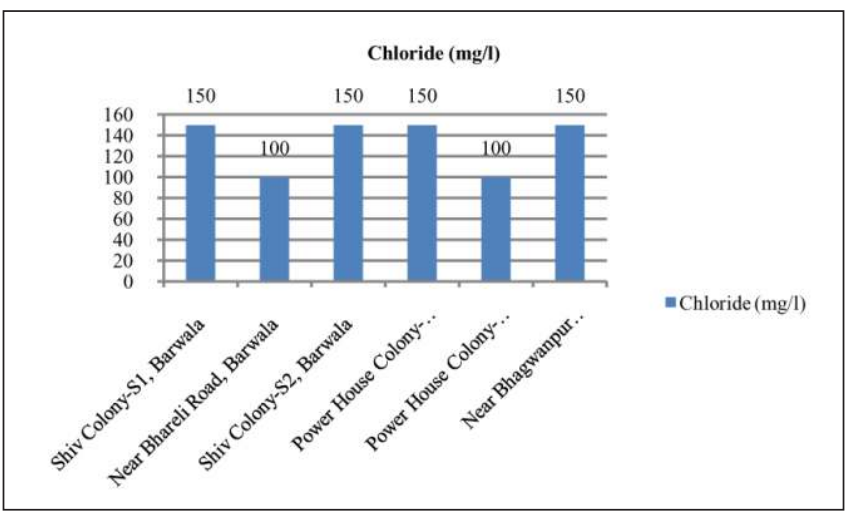

Figure 4: Chloride in groundwater samples.

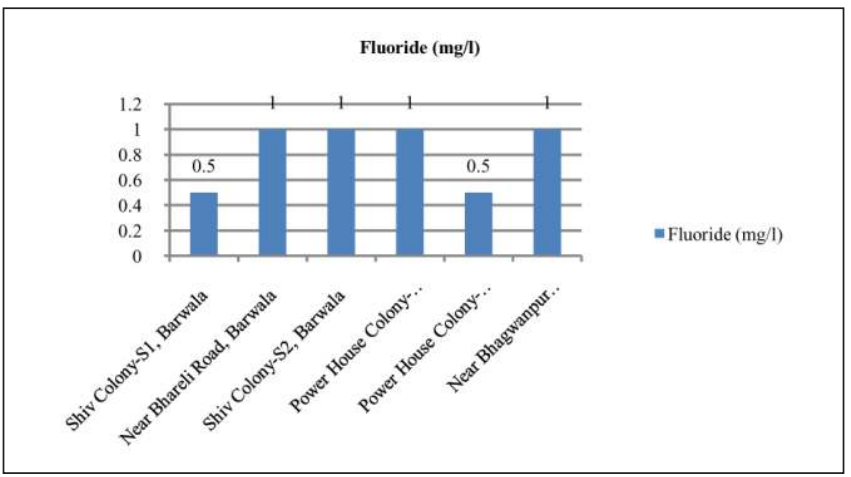

Figure 5: Fluoride in groundwater samples.

\section{Iron}

In the study area, iron ranges from $0 \mathrm{mg} / \mathrm{l}$ to $5.0 \mathrm{mg} / \mathrm{l}$.Iron is desirable in groundwater samples at Power House Colony-S1, Batawar (0.3 mg/l), Near Bhagwanpur Road, Batawar (0 mg/l),Power House Colony-S2, Batawar (0.3 mg/l) and nonpotable in groundwater samples at Shiv Colony-S1, Barwala 
(1.0 mg/l), Near Bhareli Road, Barwala (2.0 mg/l), Shiv Colony-S2, Barwala (5.0 mg/l) (Figure 6).

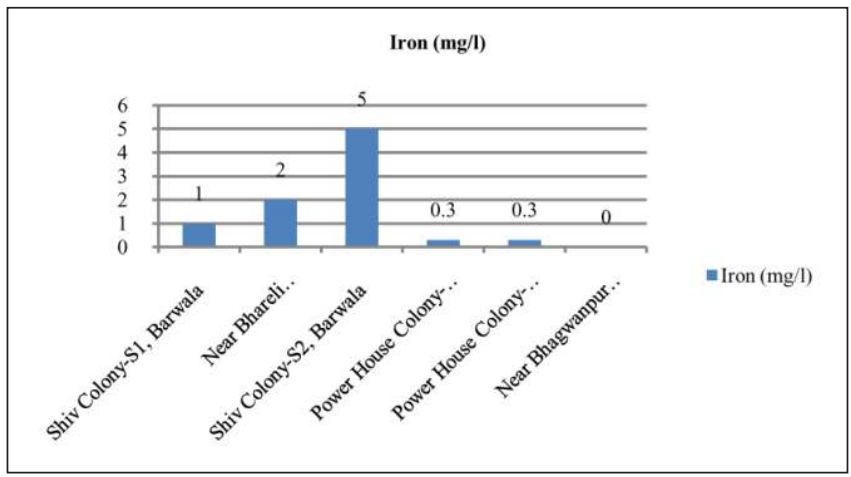

Figure 6: Iron in groundwater samples.

\section{Ammonia}

In the study area, ammonia ranges from $0.5 \mathrm{mg} / \mathrm{l}$ to $5.0 \mathrm{mg} / \mathrm{l}$. Ammonia is desirable in groundwater samples atShiv Colony-S2, Barwala (0.5 mg/l),Near Bhagwanpur Road, Batawar (0.5 mg/l) and non-portable in groundwater samples at Shiv Colony-S1, Barwala (2.0 mg/l), Near Bhareli Road, Barwala (5.0 mg/l), Power House Colony-S1, Batawar (5.0 $\mathrm{mg} / \mathrm{l}$ ),Power House Colony-S2, Batawar (5.0 mg/l) (Figure 7).

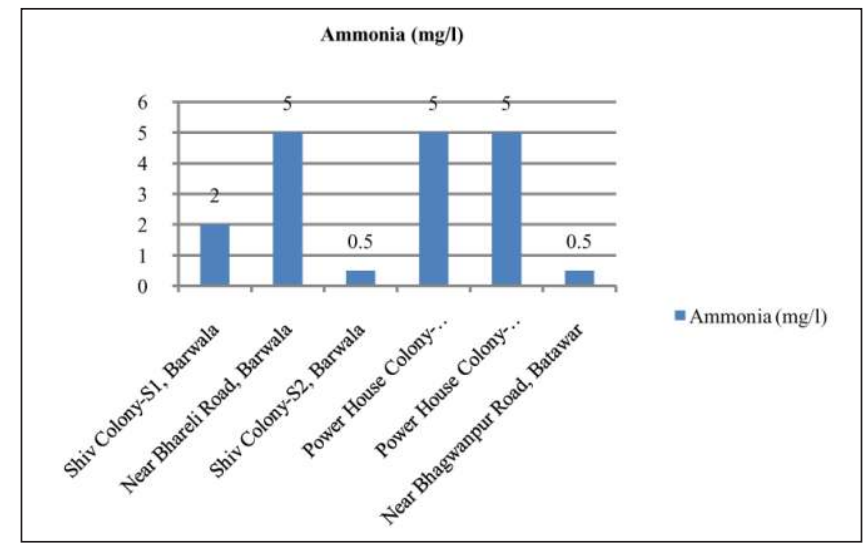

Figure 7: Ammonia in groundwater samples.

\section{Nitrite}

In the study area, nitrite ranges from $0.2 \mathrm{mg} / \mathrm{l}$ to $1 \mathrm{mg} / \mathrm{l}$. Nitrite is desirable in allthe six groundwater samples - Shiv ColonyS1, Barwala (0.5 mg/l), Near Bhareli Road, Barwala (0.2 $\mathrm{mg} / \mathrm{l})$, ShivColony-S2, Barwala $(0.2 \mathrm{mg} / \mathrm{l})$, Power House Colony-S1, Batawar (1.0 mg/l), Near Bhagwanpur Road, Batawar(0.2 mg/l) and Power House Colony-S2, Batawar (0.5 mg/l) (Fig.8).

\section{Nitrate}

In the study area, nitrate ranges from $20 \mathrm{mg} / \mathrm{l}$ to $150 \mathrm{mg} / \mathrm{l}$. Nitrate is desirable in groundater samples atShiv Colony-S2, Barwala Town (45 mg/l), Near Bhagwanpur Road, Batawar (45 mg/l) andnon-portable in groundwater samples atShiv Colony-S1, Barwala (100 mg/l), Near Bhareli Road, Barwala (150 mg/l), Power House Colony-S1, Batawar (100 mg/l) andPower House Colony-S2,Batawar (100 mg/l) (Figure 9).

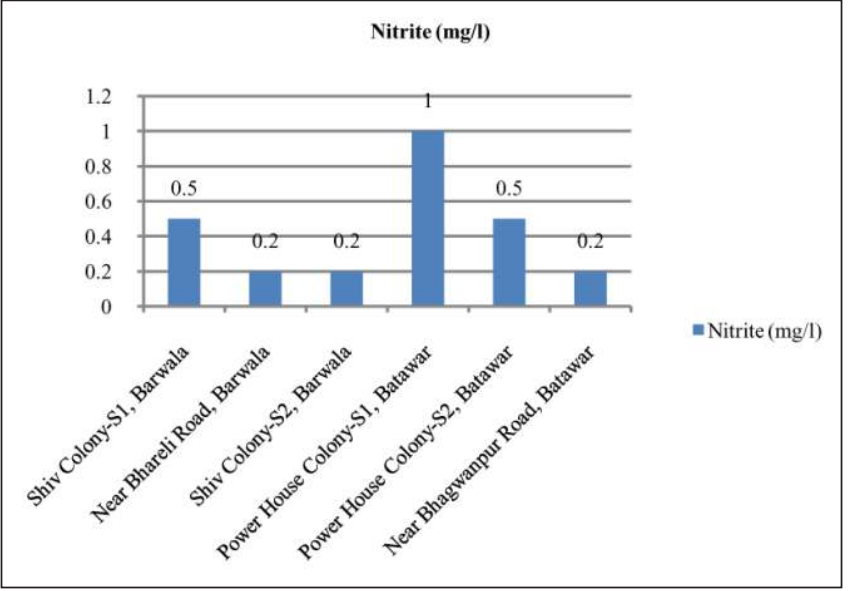

Figure 8: Nitrite in groundwater samples.

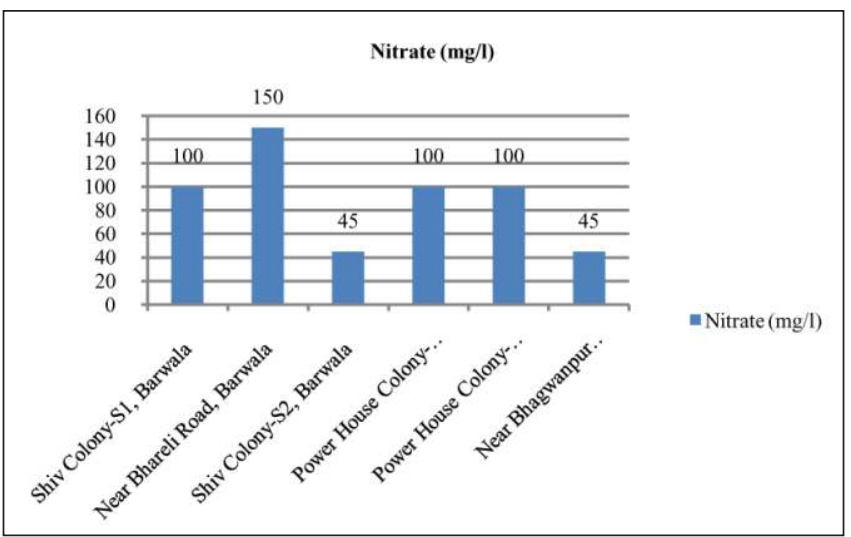

Figure 9: Nitrate in groundwater samples.

\section{Phosphate}

In the study area, phosphate ranges from $0.5 \mathrm{mg} / \mathrm{l}$ to $1.0 \mathrm{mg} / \mathrm{l}$. Phosphate is desirable in all the six groundwater samplesShiv Colony-S1, Barwala (1.0 mg/l), Near Bhareli Road, Barwala $(0.5 \mathrm{mg} / \mathrm{l})$, Shiv Colony-S2, Barwala $(0.5 \mathrm{mg} / \mathrm{l})$, Power House Colony-S1, Batawar(0.5 mg/l), Near Bhagwanpur Road, Batawar (1.0 mg/l), Power House Colony-S2, Batawar (1.0 mg/l) (Figure 10).

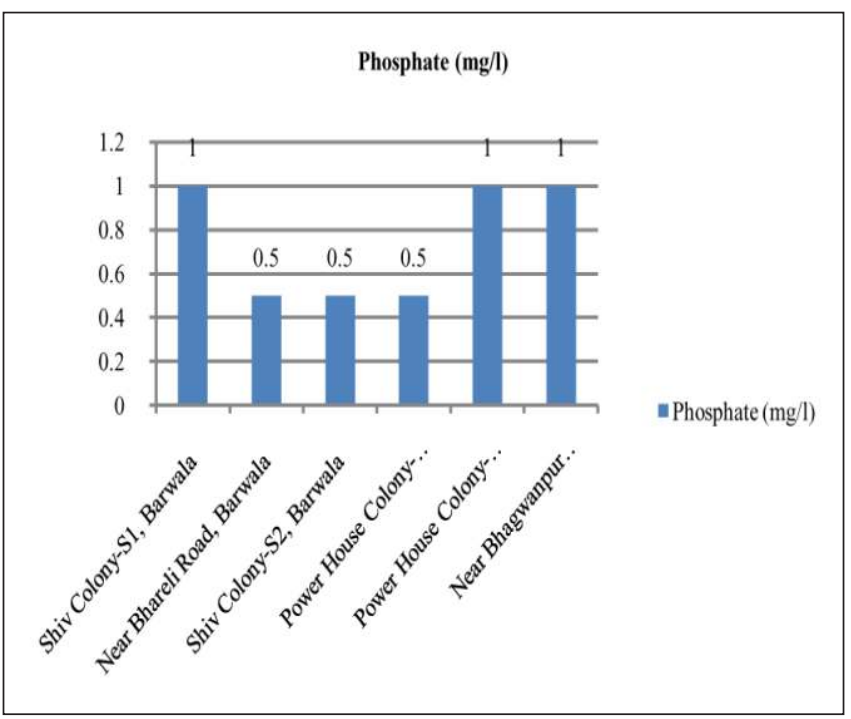

Figure 10: Phosphate in ground water samples. 


\section{Residual Chlorine}

In the study area, residual chlorine ranges from $0 \mathrm{mg} / \mathrm{l}$ to 0.5 $\mathrm{mg} / \mathrm{l}$. Residual Chlorine is desiarable in five groundwater samples- Shiv Colony-S1, Barwala (0.2 mg/l), Shiv ColonyS2, Barwala (0.2 mg/l), Power House Colony-S1, Batawar (0.2 mg/l), Near Bhagwanpur Road, Batawar (0 mg/l), Power House Colony-S2, Batawar (0.2 $\mathrm{mg} / \mathrm{l})$ and permissible in Near Bhareli Road, Barwala (0.5 mg/l) groundwater sample (Figure 11).

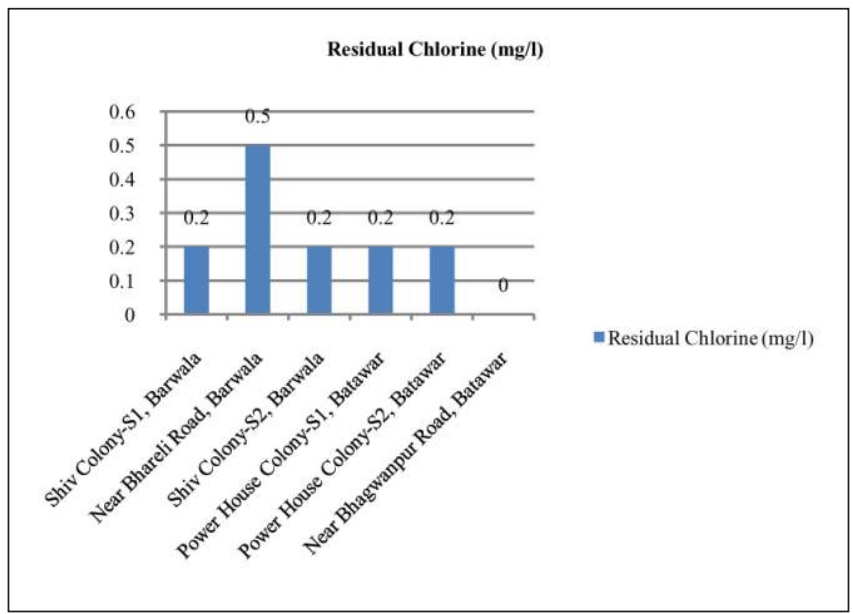

Figure 11: Residual Chlorine in groundwater samples.

\section{Groundwater Quality At Sample Sites}

\section{Shiv Colony-S1, Barwala}

In groundwater sample at Shiv Colony-S1, Barwala $\mathrm{pH}$ (desirable), hardness (permissible), chloride (desirable), fluoride (desirable), iron (non-potable), ammonia (nonpotable), nitrite (desirable), nitrate (non- potable), phosphate (desirable) and residual chlorine (desirable) (Figure 12). Overall the groundwater is non-potable due to high iron, ammonia and nitrate.

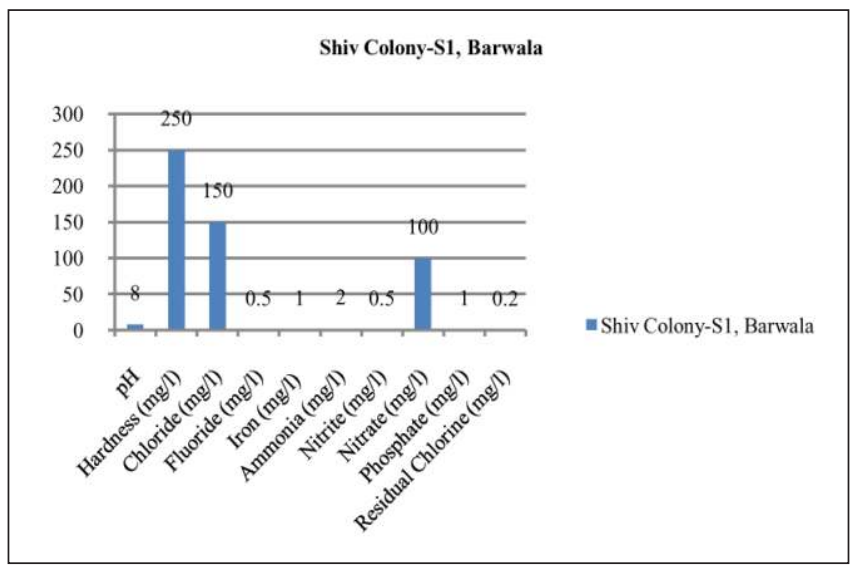

Figure 12: Groundwater quality at Shiv Colony-S1, Barwala.

\section{Shiv Colony-S2, Barwala}

In groundwater sample at Shiv Colony-S2, Barwala $\mathrm{pH}$ (desirable), hardness (permissible), chloride (desirable), fluoride (desirable), iron (non-potable), ammonia (desirable), nitrite (desirable), nitrate(desirable), phosphate (desirable) and residual chlorine (desirable) (Figure 13). Overall the groundwater is non-potable due to high iron in the groundwater.

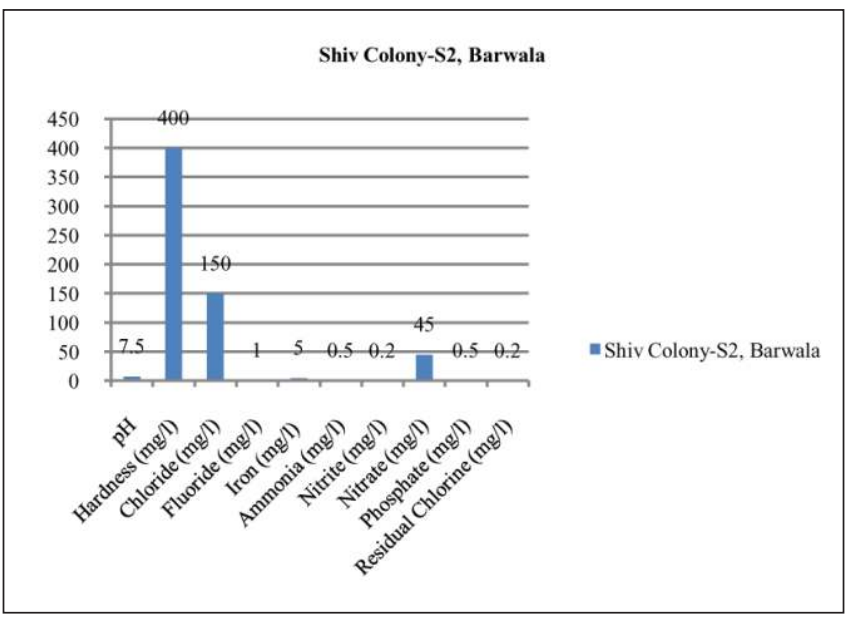

Figure 13: Groundwater quality at Shiv Colony-S2, Barwala.

\section{Near Bhareli Road, Barwala}

In groundwater sample at Near Bhareli Road, Barwala $\mathrm{pH}$ (desirable), hardness (permissible), chloride (desirable), fluoride (desirable), iron (non-potable), ammonia (nonpotable), nitrite (desirable), nitrate (non-potable), phosphate (desirable) and residual chlorine (desirable) (Figure 14). Overall the groundwater is non-potable due to high iron, ammonia and nitrate.

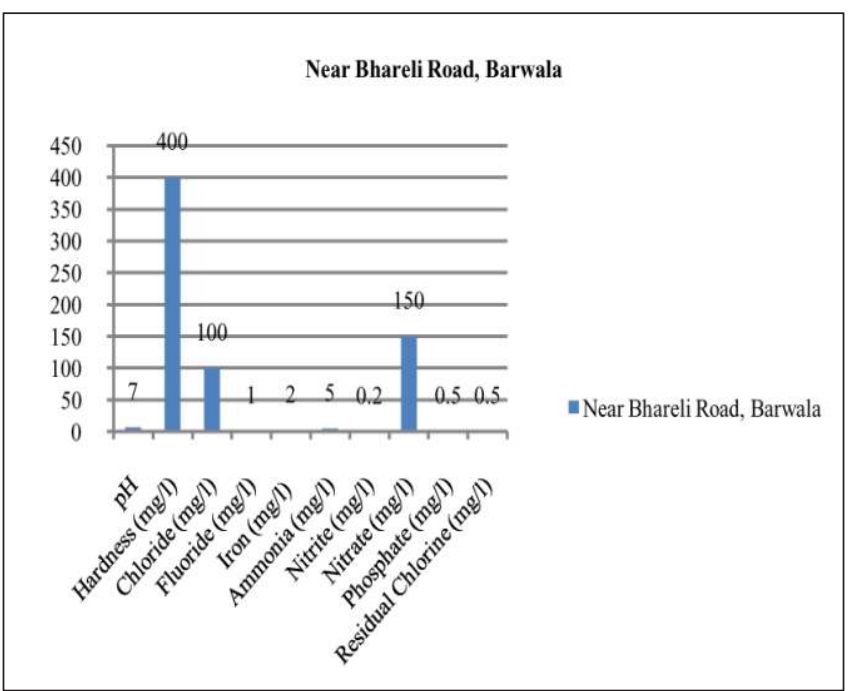

Figure 14: Groundwater quality at Near Bhareli Road, Barwala.

\section{Power House Colony-S1, Batawar}

In groundwater sample at Power House Colony-S1, Batawar $\mathrm{pH}$ (desirable), hardness (desirable), chloride (desirable), fluoride (desirable), iron (desirable), ammonia (non-potable), nitrite (desirable), nitrate (non-potable), phosphate (desirable) and residual chlorine (desirable) (Figure 15). Overall the groundwater is non-potable due to high ammonia and nitrate. 


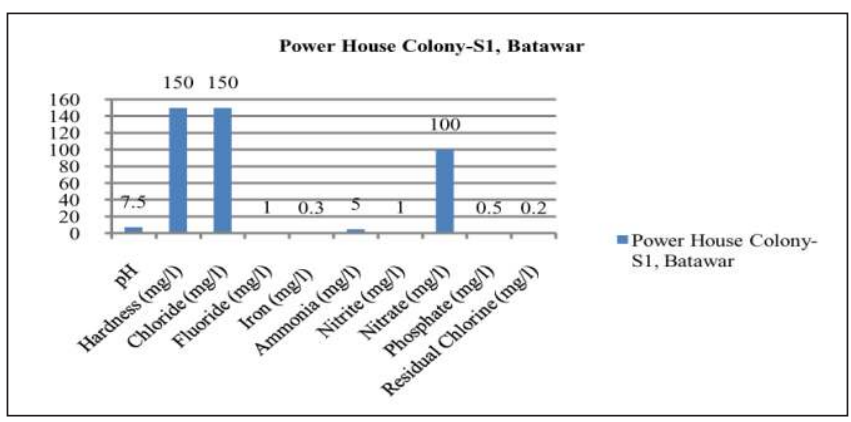

Figure 15: Groundwater quality at Power House ColonyS1, Batawar.

\section{Power House Colony-S2, Batawar}

In groundwater sample at Power House Colony-S2, Batawar $\mathrm{pH}$ (desirable), hardness (permissible), chloride (desirable), fluoride (desirable), iron (desirable), ammonia (non-potable), nitrite (desirable), nitrate (non-potable), phosphate (desirable) and residual chlorine (desirable) (Figure 16).Overall the groundwater is non-potable due to high ammonia and nitrate.

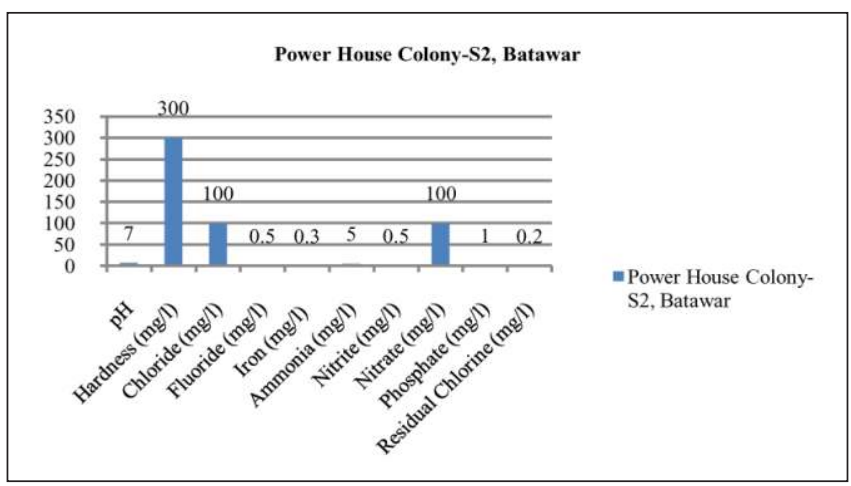

Figure 16: Groundwater quality at Power House ColonyS2, Batawar.

\section{Near Bhagwanpur Road, Batawar}

In groundwater sample at Near Bhagwanpur Road, Batawar $\mathrm{pH}$ (desirable), hardness (permissible), chloride (desirable), fluoride (desirable), iron (desirable), ammonia (desirable), nitrite (desirable), nitrate (desirable), phosphate (desirable) and residual chlorine (desirable) (Figure 17). Overall the groundwater is drinkable because all the analysed chemical parameters are under potable category of BIS drinking water standards (IS 10500:2012).



Figure 17:Groundwater quality at Near Bhagwanpur Road, Batawar.

\section{CONCLUSIONS}

In the study area $\mathrm{pH}$ ranges from 7 to 8 and desirable for drinking purpose in all the six groundwater samples. Hardness ranges from $150 \mathrm{mg} / \mathrm{l}$ to $400 \mathrm{mg} / \mathrm{l}$ and desirable in one groundwater sample and permissible in groundwater samples at Shiv Colony-S1, Barwala (250 mg/l), Near Bharel Road, Barwala (400 mg/l), Shiv Colony-S2, Barwala (400 mg/l), Near Primary Health Centre, Barwala (360 mg/l), Near Bhagwanpur Road, Batawar (310 mg/l), Power House Colony-S2, Batawar (300 mg/l). Chloride ranges from 100 $\mathrm{mg} / \mathrm{l}$ to $150 \mathrm{mg} / \mathrm{l}$ and desirable in all the six groundwater samples. Fluoride ranges from $0.5 \mathrm{mg} / \mathrm{l}$ to $2 \mathrm{mg} / \mathrm{l}$ and desirable in all the six groundwater samples. Iron ranges from $0 \mathrm{mg} / \mathrm{l}$ to $5.0 \mathrm{mg} / \mathrm{l}$ and desirable in three groundwater samples and nonpotable in groundwater samples at Shiv Colony-S1, Barwala (1.0 mg/l), Near Bhareli Road, Barwala (2.0 mg/l),Shiv Colony-S2, Barwala (5.0 mg/l), Near Primary Health Centre, Barwala (3.0 mg/l). Ammonia ranges from $0.5 \mathrm{mg} / \mathrm{l}$ to 5.0 $\mathrm{mg} / \mathrm{l}$ and desirable in two groundwater samples and nonpotable in groundwater samples at Shiv Colony-S1, Barwala (2.0 mg/), Near Bhareli Road, Barwala (5.0 mg/l), Power House Colony-S1, Batawar (5.0 mg/l), Power House ColonyS2, Batawar (5.0 mg/l). Nitrite ranges from $0.2 \mathrm{mg} / \mathrm{l}$ to $1 \mathrm{mg} / \mathrm{l}$ and desirable in all the six groundwater samples. Nitrate ranges from $45 \mathrm{mg} / \mathrm{l}$ to $150 \mathrm{mg} / \mathrm{l}$ and desirable in two groundwater samples and non-portable in groundwater samples at Shiv Colony-S1, Barwala (100 mg/l), Near Bhareli Road, Barwala (150 mg/l), Power House Colony-S1, Batawar (100 mg/l) andPower House Colony-S2,Batawar (100 mg/l). Phosphate ranges from $0.5 \mathrm{mg} / \mathrm{l}$ to $1.0 \mathrm{mg} / \mathrm{l}$ and desirable in all the six groundwater samples. Residual chlorine ranges from 0 $\mathrm{mg} / \mathrm{l}$ to $0.5 \mathrm{mg} / \mathrm{l}$ and desirable in five groundwater samples and permissible in Near Bhareli Road, Barwala (0.5 mg/l) groundwater sample. Shiv Colony-S1, Barwala groundwater is non-potable due to high iron, ammonia and nitrate, Shiv Colony-S2, Barwala groundwater is non-potable due to high iron in the groundwater, Near Bhareli Road, Barwala groundwater is non-potabledue to high iron, ammonia and nitrate, Power House Colony-S1, Batawar groundwater is non-potable due to high ammonia and nitrate, Power House Colony-S2, Batawar groundwater is non-potable due to highammonia and nitrate, Near Bhagwanpur Road, Batawar groundwater is drinkable because all the analysed chemical parameters are under potable category.

\section{REFERENCES}

1. Agrawal, Ranjana (2009).Study of physico-chemical parameters of groundwater quality of Dudu town in Rajasthan, Rasayan Journal Chem.,2 (4): 969-971.

2. Ana Elizabeth, MarínCelestino, Diego Armando Martínez Cruz, Elena Maria Otazo Sanchez, Francisco Gavi Reyes and David Vasquez Soto(2018).Groundwater quality assessment: an improved approach to K-means clustering, principal component analysis and spatial analysis: acase study, Water,10 (437):1-21.

3. Balakrishnan, P., Saleem, Abdul and Mallikarjun, $\mathbf{N}$. D. (2011).Groundwater quality mapping using geographic information system (GIS):A case study of 
Gulbarga City, Karnataka, India, African Journal of Environmental Science and Technology, 5(12):10691084.

4. Das, Shreya and Nag, S.K. (2015).Deciphering groundwater quality for irrigation and domestic purposes-a case study in Suri I and II blocks, Birbhum District, West Bengal, India,Journal Earth System Sciences, 124 (5): 965-992.

5. Durgadevagi, S., Annadurai, R. and Meenu, Mohan (2016).Spatial and temporal mapping of groundwater quality using GIS based water quality index (acasestudy of SIPCOT-Perundurai, Erode, Tamil Nadu, India), Indian Journal of Science and Technology,9 (23):1-8.

6. Hussain, Mushtaq and Prasad Rao,T. V. D. (2013). Assessment of the ground water quality and its suitability for drinking and irrigation purposes: a case study of Patancheru, Andhra Pradesh, India, Archives of Applied Science Research, 5 (6):232-238.

7. Jeihouni, M., Toomanian, A., Shahabi, M.,Alavipanah, S.K.(2014). Groundwater quality assessment for drinking purposes using GIS modelling (case study: city of Tabriz), The International Archives of the Photogrammetry, Remote Sensing and Spatial Information Sciences, vol. XL-2/W3, 2014 The 1st ISPRS International Conference on Geospatial Information Research, 15-17 November 2014, Tehran, Iran, 163-168.

8. Mah a d evas w a my, G., Nagaraju, D ., Siddalingamurthy, S., Lakshmamma, Mohammad Subhan Lone, Nagesh, P.C., Krishna Rao (2011). Groundwater quality studies in Nanjangud Taluk, Mysore District, Karnataka, India, International Journal of Environmental Sciences, 1 (7):1582-1591.

9. Okoye, N. M., Orakwe, L. C., Nwachukwu, P. C. (2016).Groundwater quality mapping using GIS: acase study of Awka, Anambra State, Nigeria,International Journal of Engineering and Management Research,6 (2), 579-584.

10. Pandian, M., and Jeyachandran, N. (2014). Groundwater quality mapping using remote sensing and GIS-acasestudy at Thuraiyur and Uppiliapuram Block, Tiruchirappalli District, Tamil Nadu, India, International Journal of Advanced Remote Sensing and GIS,3(1), 580-591.

11. Patel, R. L. and Dhiman, S. D.(2011).Temporal variation and regression analysis, of groundwater quality parameters: acase study,National Conference on Recent Trends in Engineering \& Technology, 13-14 May 2011, B.V.M. Engineering College, V.V.Nagar,Gujarat, India.

12. Rajesh, S. (2016). Impact study of groundwater quality in Sivakasi command area. Journal of Chemical and Pharmaceutical Sciences, 9(2):238-243.
13. Sarkar, Atanu, Krishnapillai, Mano, Valcour, James (2012). A study of groundwater quality of private wells in Western Newfoundland Communities, Report, The Harris Centre, Memorial University, Canada, 1-25.

14. Satyanarayana, P., Appala Raju, Harikrishna,N., K. and Viswanath, K. (2013).Urban groundwater quality assessment: acase study of Greater Visakhapatnam Municipal Corporation Area (GVMC), Andhra Pradesh, India. International Journal of Engineering Science Invention, 2(5):20-31.

15. Saxena, Umesh and Saxena, Swati (2015).Correlation study on physico-chemical parameters and quality assessment of ground water of Bassi tehsil of district Jaipur, Rajasthan, India. International Journal of Environment, Science andTechnology,1(1):78-91.

16. Sengupta, M. and Dalwani, R. (2008). Assessment of surface and groundwater quality of Hebbal Lake, Bangalore-case study, Edited Proceedings of Taal 2007:The $12^{\text {th }}$ World Lake Conference, 1737-1741.

17. Shahida Perween and Ummatul Fatima (2015).Study of groundwater quality by the assessment of physicochemical parameters and water quality index in Aligarh, Uttar Pradesh. Journal of Chemical and Pharmaceutical Research, 7(5):761-771.

18. Sheikh, Muzzafar Ahmad and Kumari, Rina (2017).A geospatial approach for delineation of groundwater potential zones in a part of national capital region, India. International Research Journal of Earth Sciences, 5(10):1-10.

19. Sinha, A.K., Kumar, Vinay and Singh, P.K. (2018). GIS Approach based groundwater quality assessment and evaluation for irrigation purpose in a hard rock hilly terrain of Western India. International Journal of Current Microbiology and Applied Sciences, Special Issue-7:1313-1332.

20. Subramani, T., Krishnan, S., Kumaresan, P. K. (2012).Study of groundwater quality with GIS application for Coonoor Taluk in Nilgiri District, International Journal of Modern Engineering Research, 2(3):586-592.

21. Thomas Spanos, Antoaneta Ene, Christina Xatzixistou, Agelos Papaioannou (2015). Assessment of groundwater quality and hydrogeological profile of Kavala area, Northern Greece, Romanian. Journal of Physics, 60 (7-8):1139-1150.

22. Topper, Ralf and Horn, Andy(2011).El Paso County groundwater quality study Phase 1,Colorado Geological Survey, 1-139.

23. Vashisth, Ayush (2017). Analysis of water quality of Murthal in Haryana, International Journal of Dynamics of Fluids, 13 (2):243-249. 